\title{
Genetic diversity of Leptospira in northwestern Colombia: first report of Leptospira santarosai as a recognised leptospirosis agent
}

\author{
Ronald Guillermo Peláez Sanchez', Juan Álvaro Lopez', Martha María Pereira², \\ Margarita Arboleda Naranjo ${ }^{3}$, Piedad Agudelo-Flórez ${ }^{4}+$
}

\begin{abstract}
${ }^{1}$ University of Antioquia, School of Microbiology, Medellín, Antioquia, Colombia ${ }^{2}$ Fundação Oswaldo Cruz, Instituto Oswaldo Cruz, Centro Colaborador da OPAS/OMS para Leptospirose, Rio de Janeiro, RJ, Brasil ${ }^{3}$ University CES, Antonio Roldán Betancur Hospital,

Colombian Institute of Tropical Medicine, Antioquia, Colombia ${ }^{4}$ University CES, Faculty of Medicine, Medellín, Antioquia, Colombia
\end{abstract}

The region of Antioquia in northeastern Colombia has the highest number of reported leptospirosis cases in the country. It also shows high seroprevalence indexes in the general population and socio-environmental conditions favourable for the transmission of the disease between humans and animals. In this study, 25 Leptospira isolates from Colombia's Antioquia department were identified to the species level as L. santarosai (12), L. interrogans (9) and $\mathrm{L}$. meyeri (4) using phylogenetic analysis of the Amidohydrolase gene. Typing at the serovar level was performed using multilocus sequence typing (MLST) and monoclonal antibodies. The serovars Canalzonae, Babudieri, Alice, Beye, and Copenhageni have been identified as causing human or animal infections in Antioquia, Colombia. The four environmental isolates were not identified to the serovar level. L. santarosai serovar Canalzonae and Alice were identified as new etiologic agents of human leptospirosis in Antioquia, Colombia. This paper reports species and serovars that were previously unknown in the region.

Key words: leptospirosis - Leptospira - phylogenetic - MLST - monoclonal antibodies - PFGE - Colombia

Leptospirosis is a globally distributed zoonosis that poses a major public health problem in rural and urban areas of tropical regions. This infection is attributed to direct or indirect human contact with the urine of wild, synanthropic, or domestic animals infected with Leptospira bacteria (Evangelista \& Coburn 2010, Galloway $\&$ Levett 2010). Outbreaks of the disease in developed countries are usually associated with occupational exposure, tourism, and water sports events (CDC 1998, Morgan et al. 2002, Benschop et al. 2009, Desai et al. 2009, Stern et al. 2010). Developing countries bear the greatest burden of the disease due to the precarious living conditions of the populations exposed to the main risk factors (Bharti et al. 2003, Petrakovsky et al. 2014). While there are currently both serological and molecular classifications of Leptospira, there is no direct correlation between them. A given serogroup is often found in several Leptospira species (Cerqueira \& Picardeau 2009, Adler \& Moctezuma 2010, Saito et al. 2013). For instance, the 14 described serovars of the Bataviae serogroup are found in L. interrogans sensu stricto (five serovars), Leptospira santarosai (five serovars), Leptospira kirschneri (one serovar), Leptospira noguchii (two serovars) and Leptospira borgpetersenii (one serovar) (Cerqueira $\&$ Picardeau 2009). According to studies based on DNA/

doi: 10.1590/0074-02760160245

Financial support: COLCIENCIAS [Projects: 122865740423 (PAF), $111554531412(\mathrm{JAL})]$.

+ Corresponding author: pagudelo@ces.edu.co

Received 2 June 2016

Accepted 25 August 2016
DNA hybridisation, the genus Leptospira consists of 21 genomic species (Saito et al. 2013). Serological studies describe over 260 pathogenic serovars, grouped into 24 serogroups, and 60 saprophytic serovars (Cerqueira \& Picardeau 2009). Given the high serological and genetic diversity of Leptospira, it is important to identify the circulating species/serovars in order to enhance leptospirosis prevention and control strategies. For example, serodiagnostic tests could be improved by the incorporation of specific antigens for known native species. Likewise, vaccines could be developed specific to serovars circulating in different regions. The majority of Colombian studies have been limited to investigating leptospirosis outbreaks or studying seroprevalence in specific populations in certain regions of the country (Sebek et al. 1989, Epstein et al. 1995, Ochoa et al. 2000, Nájera et al. 2005, Ferro et al. 2006, Romero et al. 2010). However a few studies in Colombia have incorporated molecular and serological identification of clinical isolates by serological typing, multilocus sequence typing (MLST) and pulsed-field electrophoresis (WHO 2003, Szonyi et al. 2011, Romero-Vivas et al. 2013a, b). Since there is little information available about the genetic diversity of species and serovars in Colombia, it is important to identify the causative agents of human leptospirosis and its distribution in animal hosts and environmental sources.

\section{MATERIALS AND METHODS}

Source of isolates of Leptospira - Twenty-five Leptospira isolates were collected during the study. Nine of these isolates were obtained from blood sampling of patients diagnosed with leptospirosis from the municipalities of Apartadó (eight) and Puente Iglesias (one). Four isolates were obtained from the kidneys and blood 
of capuchin monkeys (Cebus capucinus) that died as a result of jaundiced leptospirosis in the municipality of Barbosa. Three isolates were obtained from urine samples from dogs in the city of Medellin, which were sent to the laboratory for suspected leptospirosis, and five isolates were obtained from kidney samples from Rattus norvegicus captured in the city of Medellin and the municipality Turbo. Finally, four isolates were obtained from environmental water sources collected in the municipalities of Triganá and Necoclí; these water sources are used as for human consumption. All isolates were grown in liquid EMJH medium supplemented with $10 \%$ EMJH enrichment medium (Becton-Dickinson Biosciences) at a temperature of $26-30^{\circ} \mathrm{C}$. The cultures were examined by dark field microscopy weekly for three months to detect Leptospira growth.

DNA extraction - DNA was extracted from $1 \mathrm{~mL}$ of culture. The turbidity of the bacterial suspensions was adjusted to $0.5 \mathrm{McF}$ arland standards. DNA extraction was performed using Wizard Kit (Promega ${ }^{\circledR}$, USA), according to the manufacturer's instructions for gramnegative bacteria. All experiments were performed at a concentration of $20 \mathrm{ng} / \mu \mathrm{L}$ DNA for isolates. Concentration and purity were determined by Nanodrop, while integrity was assessed by $1 \%$ agarose gel electrophoresis.

Amidohydrolase gene amplification - A 914-base pair fragment from the Amidohydrolase gene was amplified by polymerase chain reaction (PCR) using the primers F16S (GCGGATATGCCGAACAACCCG) and R16S (TCAAACGGGCTCCAGCCGCT). The reagent concentrations used for PCR standardisation were as follows: primers $(0.4 \mu \mathrm{M})$, dNTPs $(0.2 \mathrm{mM})$, buffer $(1 \times), \mathrm{MgCl} 2$ $(1.5 \mathrm{mM})$, Taq polymerase (1 unit/reaction) and DNA $(200 \mathrm{ng} / \mu \mathrm{L})$. The final volume for each reaction was 25 $\mu \mathrm{L}$. PCR was performed in a Perkin Elmer 9700 thermocycler. The thermal cycling profile was: one initial denaturation cycle at $94^{\circ} \mathrm{C}$ for $5 \mathrm{~min}$, followed by 35 cycles at $94^{\circ} \mathrm{C}$ for $45 \mathrm{~s}, 64^{\circ} \mathrm{C}$ for $1 \mathrm{~min}, 72^{\circ} \mathrm{C}$ for $2 \mathrm{~min}$ and a final cycle at the extension temperature of $72^{\circ} \mathrm{C}$ for $5 \mathrm{~min}$.

Species identification by phylogenetic analysis - The Amidohydrolase genes from 19 Leptospira species were used as reference sequences. These were: (WP_010573489.1, WP_020772111.1, WP_003005945.1, WP_004442891.1, WP_002745964.1, WP_004768995.1, WP_010577276.1, WP_046951104.1, WP_000591986.1, WP_039948702.1, WP_020987613.1, WP_002972272.1, WP_039935685.1, WP_002977290.1, WP_015682624.1, WP_015676897.1, WP_004786049.1, WP_016546771.1, and WP 012387340.1). These sequences and those obtained from the isolates by sequencing were aligned using the ClustalX program (Larkin et al. 2007). Phylogenetic analysis was performed with using MEGA6 phylogenetic software (Tamura et al. 2011), using the Neighbour-Joining method with 1000 bootstrap replicates. Evolutionary distances were computed using the parametric method Kimura-2.

Serovar identification by MLST - Molecular identification of the Leptospira isolates was performed using MLST, as described by (Boonsilp et al. 2013). In brief, seven genes that are constitutively expressed in Leptospira (glmU, pntA, sucA, tpiA, pfkB, mreA, and CaiB) were amplified and sequenced. Subsequently, these sequences were queried against a database (http://leptospira.mlst.net/) to determine their allelic profile and phylogenetic relationship to the reference strains previously included in the database.

Serovar identification by pulsed field gel electrophoresis - Pulsed field gel electrophoresis (PFGE) was performed using the NotI restriction enzyme to generate fingerprint patterns, as previously described by (Machry et al. 2010). Pulse marker 0.5-1000 kb (SIGMA) was used as a size standard. Fingerprint patterns were analysed using GelCompar II (Gel electrophoresis software, Applied Maths). Dendrograms were created from UPGMA cluster analyses based on the Dice band-based coefficient. Band comparison settings of $1.5 \%$ optimisation and $1 \%$ position tolerance were used. Fingerprint patterns for the clinical isolates were queried against a library of 19 reference serovars based on mean similarity. Those with fingerprint patterns matching reference patterns in the library were identified to serovar level (Tenover et al. 1995).

Serovar identification by monoclonal antibodies Monoclonal antibodies (F70C14, F70C24 and F70C12) were used to differentiate the Icterohaemorrhagiae and Copenhageni serovars. The reference immune sera were provided by the Royal Tropical Institute (KIT) in the Netherlands. The reference strains $L$. interrogans (serogroup Icterohaemorrhagiae, serovar Icterohaemorrhagiae, RGA) and L. interrogans (serogroup Icterohaemorrhagiae, serovar Copenhageni, M20) were used as controls for the tests. Serial dilutions $(1 / 20)$ were performed to determine antibody titres (Tenover et al. 1995).

Clinical, laboratory and epidemiological data - Five patients enrolled in this study were subjected to physical examinations. Peripheral blood samples were collected in the hospitals where these patients were admitted, and sent to the Colombian Institute of Tropical Medicine for laboratory tests (Indirect Immuno-fluorescence test (IIFT), microscopic agglutination test (MAT) and blood culture. Finally, the patients' possible exposure to potential risk factors was evaluated with an epidemiological survey.

\section{RESULTS}

Species identification by phylogenetic analysis - The species patterns were divided into three main branches according to their pathogenicity status (pathogenic, intermediate, and saprophytic). Branch support values ranged between $20-100 \%$, permitting the identification of 19 Leptospira species. Isolates from humans, dogs, rodents, and capuchin monkeys (C. capucinus) clustered with the pathogenic species. Isolates from humans and canines were identified as $L$. santarosai (branch support values of $100 \%$ ), while isolates from capuchin monkeys and rodents were identified as L. interrogans (branch support values of 99\%). Finally, isolates from environmental water sources were grouped with saprophytic species. These were identified as L. meyeri (branch support values of $100 \%$, Fig. 1, Table V). 


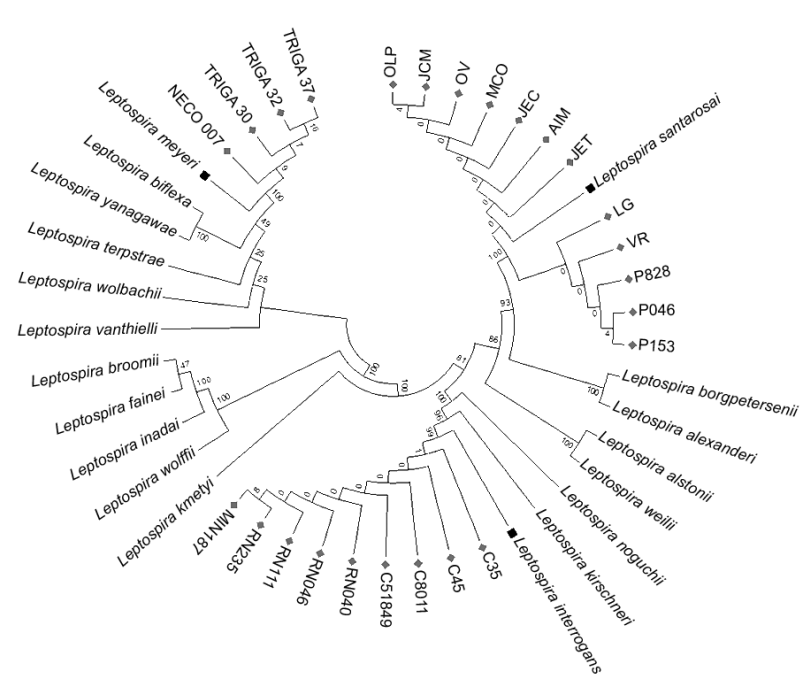

Fig. 1: species identification by phylogenetic analysis of the Amidohydrolase gene. A diamond and square represent isolates of Leptospira and the reference species genetically related to isolates, respectively.
Serovar identification by MLST - MLST methodology was used to verify correct species identification results from the phylogenetic analysis of the Amidohydrolase gene, and to identify twelve isolates to the serovar level. Five isolates obtained from humans were identified as the L. santarosai serovar Alice, and four human isolates were identified as the $L$. santarosai serovar Canalzonae. Two isolates from canines were identified as the L. santarosai serovar Beye, and one canine isolate was identified as the L. santarosai serovar Babudieri. The four isolates from capuchin monkeys and five isolates from rodents could not be identified to the serovar level. There was a $100 \%$ correlation between the results obtained by MLST and those obtained by the phylogenetic identification method (Tables I, V). The environmental isolates were not identified to the serovar level by MLST, due to the absence of allelic profiles in the MLST database.

Pulsed-field gel electrophoresis standardisation - Five isolates from rodents were identified by PFGE, as L. interrogans serovar Icterohaemorrhagiae or Copenhageni (Fig. 2, Table V). There was a 100\% corre-

TABLE I

Identification to serovar level of 12 Leptospira isolates by multilocus sequence typing (MLST) methodology

\begin{tabular}{lccccccc}
\hline Code & Species & Serogroup & Serovar & ST & Allelic profile & Country & Source \\
\hline CZ188 & L. santarosai & Grippotyphosa & Canalzonae & 176 & $41,53,52,49,57,43,43$ & Panamá & spiny rat \\
1 & L. santarosai & Grippotyphosa & Canalzonae & 176 & $41,53,52,49,57,43,43$ & Colombia & human \\
2 & L. santarosai & Grippotyphosa & Canalzonae & 176 & $41,53,52,49,57,43,43$ & Colombia & human \\
3 & L. santarosai & Grippotyphosa & Canalzonae & 176 & $41,53,52,49,57,43,43$ & Colombia & human \\
7 & L. santarosai & Grippotyphosa & Canalzonae & 176 & $41,53,52,49,57,43,43$ & Colombia & human \\
1537 U & L. santarosai & Shermani & Babudieri & 172 & $40,48,47,47,52,42,42$ & Perú & pig \\
16 & L. santarosai & Shermani & Babudieri & 172 & $40,48,47,47,52,42,42$ & Colombia & canine \\
CI40 & L. santarosai & Autumnalis & Alice & 173 & $40,53,51,48,56,44,43$ & Sri Lanka & human \\
4 & L. santarosai & Autumnalis & Alice & 173 & $40,53,51,48,56,44,43$ & Colombia & human \\
5 & L. santarosai & Autumnalis & Alice & 173 & $40,53,51,48,56,44,43$ & Colombia & human \\
6 & L. santarosai & Autumnalis & Alice & 173 & $40,53,51,48,56,44,43$ & Colombia & human \\
8 & L. santarosai & Autumnalis & Alice & 173 & $40,53,51,48,56,44,43$ & Colombia & human \\
9 & L. santarosai & Autumnalis & Alice & 173 & $40,53,51,48,56,44,43$ & Colombia & human \\
Alice & L. santarosai & Mini & Beye & 178 & $43,51,47,48,55,45,43$ & Panamá & spiny rat \\
14 & L. santarosai & Mini & Beye & 178 & $43,51,47,48,55,45,43$ & Colombia & canine \\
15 & L. santarosai & Mini & Beye & 178 & $43,51,47,48,55,45,43$ & Colombia & canine \\
\hline
\end{tabular}

\begin{tabular}{|c|c|c|c|c|c|}
\hline Species & Serogroup & Serovar & Strain & DC (\%) & PFGE \\
\hline L.interrogans & Icterohaemorrhagiae & Icterohaemorrhagiae & RGA & & 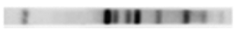 \\
\hline L.interrogans & Icterohaemorrhagiae & Copenhageni & M20 & & an 1 nata \\
\hline L.interrogans & Icterohaemorrhagiae & Icterohaemorrhagiae / Copenhageni & 17 & $100 \%$ & en at 1 . \\
\hline L.interrogans & Icterohaemorrhagiae & Icterohaemorrhagiae / Copenhageni & 18 & $100 \%$ & $x=0$ \\
\hline L.interrogans & Icterohaemorrhagiae & Icterohaemorrhagiae / Copenhageni & 19 & $100 \%$ & 111. \\
\hline L.interrogans & Icterohaemorrhagiae & Icterohaemorrhagiae / Copenhageni & 20 & $88.88 \%$ & $11=$ \\
\hline L.interrogans & Icterohaemorrhagiae & Icterohaemorrhagiae / Copenhageni & 21 & $100 \%$ & 1 \\
\hline
\end{tabular}

Fig. 2: identification of five isolates from rodents by pulsed field gel electrophoresis (PFGE). The genomic restriction profiles were consistent with the profiles corresponding to serovar Icterohaemorrhagiae or serovar Copenhageni. 
TABLE II

Identification of nine isolates from rodents and capuchin monkeys (Cebus capucinus) by monoclonal antibodies. The agglutination reactions identified nine isolates belonging to serovar Copenhageni

\begin{tabular}{|c|c|c|c|}
\hline Monoclonal antibody & Serogroup-specific & \multicolumn{2}{|c|}{ Serovar-specific } \\
\hline F70C14 & Icterohaemorrhagiae & \multicolumn{2}{|c|}{ Icterohaemorrhagiae } \\
\hline $\mathrm{F} 70 \mathrm{C} 24$ & Icterohaemorrhagiae & \multicolumn{2}{|c|}{ Copenhageni } \\
\hline $\mathrm{F} 89 \mathrm{C} 12$ & Icterohaemorrhagiae & \multicolumn{2}{|c|}{ No Icterohaemorrhagiae } \\
\hline \multirow[t]{2}{*}{ Antigens } & \multicolumn{3}{|c|}{ Monoclonal antibody } \\
\hline & F70C14 title & F70C24 title & F89C12 title \\
\hline RGA (serovar Icterohaemorrhagiae) & 20,480 & negative & negative \\
\hline M20 (serovar Copenhageni) & negative & 10,420 & 2,560 \\
\hline (10) C35 & negative & 20,480 & 2,560 \\
\hline (11) C45 & negative & 20,480 & 640 \\
\hline (12) C8011 & negative & 20,480 & 5,120 \\
\hline (13) C51849 & negative & 20,480 & 640 \\
\hline (17) RN040 & negative & 20,480 & 2,560 \\
\hline (18) RN046 & negative & 20,480 & 1,280 \\
\hline (19) RN111 & negative & 20,480 & 640 \\
\hline (20) RN235 & negative & 20,480 & 5,120 \\
\hline (21) MIN187 & negative & 20,480 & 640 \\
\hline
\end{tabular}

TABLE III

Epidemiological data from five patients diagnosed with leptospirosis

\begin{tabular}{|c|c|c|c|c|c|}
\hline Epidemiological Data & $\begin{array}{c}\text { Patient } 1 \\
\text { Serovar Canalzonae }\end{array}$ & $\begin{array}{c}\text { Patient } 2 \\
\text { Serovar Canalzonae }\end{array}$ & $\begin{array}{c}\text { Patient } 3 \\
\text { Serovar Canalzonae }\end{array}$ & $\begin{array}{c}\text { Patient } 4 \\
\text { Serovar Alice }\end{array}$ & $\begin{array}{c}\text { Patient } 5 \\
\text { Serovar Alice }\end{array}$ \\
\hline Age & 7 & 13 & 26 & 39 & 48 \\
\hline Sex & Male & Male & Male & Male & Female \\
\hline Occupation & Student & Student & Employee & Farmer & Housewife \\
\hline Origin & Urban area & Urban area & Urban area & Rural area & Rural area \\
\hline Aqueduct & Yes & Yes & No & No & No \\
\hline Sewerage & Yes & Yes & No & No & No \\
\hline Drinking water & Yes & Yes & No & No & No \\
\hline Artesian well & No & No & Yes & No & No \\
\hline Contact with mice & Yes & Yes & Yes & Yes & Yes \\
\hline Contact with dogs & No & No & Yes & Yes & Yes \\
\hline Contact with other mammals & No & No & Yes & Yes & Yes \\
\hline Bathing in streams & No & Yes & No & No & No \\
\hline Nearby farms flooded & Yes & No & Yes & Yes & Yes \\
\hline
\end{tabular}

lation between the results obtained by PFGE and those obtained by MLST. Environmental, human, and canine isolates were not identified to the serovar level by PFGE, due to the insufficient number of cleavage events by the NotI enzyme on the genomes of these species.

Serovar identification by monoclonal antibodies Isolates from dogs and rodents that could not be identified to the serovar level using MLST or PFGE were identified using monoclonal antibodies as belonging to the Copenhageni serovar. The nine isolates had positive agglutination reactions with the monoclonal antibodies F70C24 and F89C12, with titres between 1/640 and $1 / 5120$. They had no agglutination reaction with the monoclonal antibody F70C14, which is specific to the serovar Icterohaemorrhagiae (Tables II, V).

Clinical, laboratory and epidemiological patient data - The clinical histories and laboratory test results of five patients are shown in (Table III), according to random 


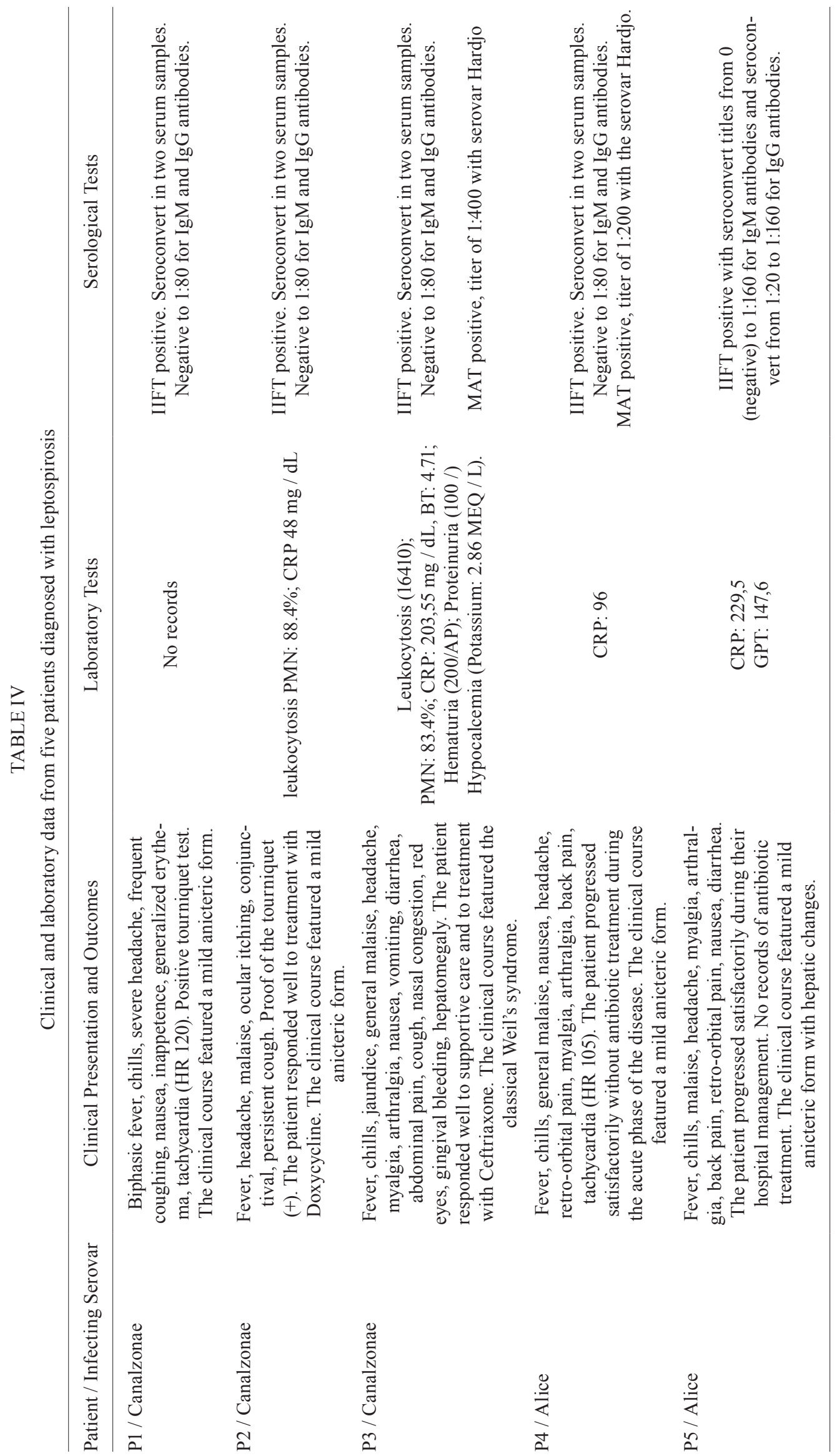


patient numbering (P1-P5) and the respective infecting serovar. The epidemiological features related to the main risk factors and the infecting serovar are shown in (Table IV). The L. santarosai serovar Canalzonae was found to be the causative agent of leptospirosis in three patients. One patient showed clinical signs and symptoms characteristic of Weil's disease. The L. santarosai serovar Alice was found to be the causative agent of leptospirosis in two patients. The patients infected with serovar Canalzonae came from urban areas and the patients infected with the serovar Alice came from rural areas.

\section{DISCUSSION}

Characterisation of the genetic diversity of Leptospi$r a$ species and serovars distributed in the environment, including in both reservoirs and accidental hosts, is highly advantageous for improvement of serological diagnosis, immunoprophylaxis, prevention, and control of the disease. The incorporation of native serovar antigens would increase the sensitivity of serological tests, and enable the development of more effective vaccines that target specific serovars circulating in given regions. In addition, the identification of disease reservoirs further aids in the development of prevention and control strate- gies, such as those aiming to minimise the dispersion of Leptospira bacteria in the environment and decreasing human contact with infected animals.

Human and canine isolates were identified as L. santarosai. This is the first report documenting the Canalzonae, Babudieri, Alice and Beye serovars as causes of human or animal leptospirosis in Antioquia, Colombia. However, this species is a known causative agent of human leptospirosis in Costa Rica and the French West Indies (Valverde et al. 2008, Bourhy et al. 2013). Previous studies in Peru also suggest the ubiquity of L. santarosai and the possibility of animal hosts. L. santarosai has been isolated from rats, marsupials, and humans and has also been found in samples taken from the surrounding environment (Rivera et al. 2012). While Brazil and Mexico have not reported cases of human leptospirosis yet, this species has been found to infect buffalo and cattle in these countries (Vasconcellos et al. 2001, Carmona-Gasca et al. 2011).

The sensitivity of the MAT may be improved by including local strains or serovars, mainly those belonging to the species $L$. santarosai. Likewise, more effective vaccines could be developed by considering these serovars in their antigenic composition. The isolates from capuchin

\section{TABLE V}

Species level identification of twenty-five Leptospira isolates by phylogenetic analysis and identification to the serovar level from twenty-one Leptospira isolates by pulsed field gel electrophoresis (PFGE), multilocus sequence typing (MLST), and monoclonal antibodies

\begin{tabular}{|c|c|c|c|c|c|c|}
\hline Code & Isolate & Source & Origin & Phylogenetic & MLST & Monoclonal antibody \\
\hline 1 & JET & human & Apartadó & L. santarosai & Canalzonae & \\
\hline 2 & AIM & human & Puente Iglesias & L. santarosai & Canalzonae & \\
\hline 3 & JEC & human & Apartadó & L. santarosai & Canalzonae & \\
\hline 4 & $\mathrm{MCO}$ & human & Apartadó & L. santarosai & Alice & \\
\hline 5 & OV & human & Apartadó & L. santarosai & Alice & \\
\hline 6 & OLP & human & Apartadó & L. santarosai & Alice & \\
\hline 7 & $\mathrm{JCM}$ & human & Apartadó & L. santarosai & Canalzonae & \\
\hline 8 & LG & human & Apartadó & L. santarosai & Alice & \\
\hline 9 & VR & human & Apartadó & L. santarosai & Alice & \\
\hline 10 & $\mathrm{C} 35$ & C. capucinus & Barbosa & L. interrogans & unidentified & Copenhageni \\
\hline 11 & $\mathrm{C} 45$ & C. capucinus & Barbosa & L. interrogans & unidentified & Copenhageni \\
\hline 12 & C8011 & C. capucinus & Barbosa & L. interrogans & unidentified & Copenhageni \\
\hline 13 & C51849 & C. capucinus & Barbosa & L. interrogans & unidentified & Copenhageni \\
\hline 14 & P828 & canis & Medellín & L. santarosai & Beye & \\
\hline 15 & P046 & canis & Medellín & L. santarosai & Beye & \\
\hline 16 & P153 & canis & Medellín & L. santarosai & Babudieri & \\
\hline 17 & RN040 & R. norvergicus & Turbo & L. interrogans & unidentified & Copenhageni \\
\hline 18 & RN046 & R. norvergicus & Turbo & L. interrogans & unidentified & Copenhageni \\
\hline 19 & RN111 & R. norvergicus & Turbo & L. interrogans & unidentified & Copenhageni \\
\hline 20 & RN235 & R. norvergicus & Turbo & L. interrogans & unidentified & Copenhageni \\
\hline 21 & MIN 187 & R. norvergicus & Medellín & L. interrogans & unidentified & Copenhageni \\
\hline 22 & NECO 007 & water & Necoclí & L. meyeri & & \\
\hline 23 & TRIGA 30 & water & Triganá & L. meyeri & & \\
\hline 24 & TRIGA 32 & water & Triganá & L. meyeri & & \\
\hline 25 & TRIGA 37 & water & Triganá & L. meyeri & & \\
\hline
\end{tabular}


monkeys and rodents were identified as $L$. interrogans; this species is the major causative agent of leptospirosis worldwide (Levett et al. 2006). In Colombia, L. interrogans has been found to infect capuchin monkeys, rodents and pigs (Szonyi et al. 2011, Romero-Vivas et al. 2013a, b).

Copenhageni and Icterohaemorrhagiae serovars are normally included in serological tests and vaccines. Since molecular identification by MLST and PFGE could not differentiate between Copenhageni and Icterohaemorrhagiae serovars, it was necessary to use monoclonal antibodies to differentiate between these serovars. The results indicate that rodent and capuchin monkey isolates belonged to the Copenhageni serovar (Table II).

The isolates from environmental water sources were identified as L. meyeri species, which is difficult to taxonomically classify due to it pathogenic serovars, such as Sophia, and saprophytic serovars, such as Semaranga. Other L. meyeri serovars, for example Perameles and Ranarum, can be found in both pathogenic and saprophytic subgroups (Kmety \& Dikken 1993). Therefore, it is important to control the presence of this species in environmental water sources, due to its potential pathogenicity. The identification of these species in environmental water samples is also indicative that certain pathogenic strains may be able to temporarily survive outside of their animal hosts. The saprophytic L. meyeri species has not been reported in Colombia.

For epidemiological purposes, it is important to note that the three isolates identified as serovar Canalzonae came from patients living in urban areas, while isolates of serovar Alice infected patients living in rural areas. The common epidemiological factor reported for all five patients was contact with rodents in their homes (Table III). In terms of clinical characteristics, two cases (P1 and P2) were paediatric patients (under 15 years) infected with the serovar Canalzonae. One presented a biphasic course and increased indicators of acute phase disease (leucocytosis and CRP). Both patients exhibited haemorrhagic manifestations, which were evaluated by the tourniquet test. They had mild forms of leptospirosis, which were treated with amoxicillin and doxycycline. Patient P3, also infected by the serovar Canalzonae, presented clinical signs and symptoms matching Weil's syndrome (Table IV). The patients infected with the Alice serovar (P4 and P5) also presented with acute febrile illness with systemic manifestations. One of them required hospital management for hepatitis, and had increased ALT (160.2 $\mathrm{mg} / \mathrm{dL})$, and increased total bilirubin $(2.29 \mathrm{mg} / \mathrm{dL})$ at the expense of direct bilirubin $(1.8 \mathrm{mg} / \mathrm{dL})$. Other laboratory examinations showed a tendency toward leucopoenia, with mild thrombocytopaenia and enhanced CRP (227.5 $\mathrm{mg} / \mathrm{dL}$ ) (Table IV). The symptomatology of patients infected with the Canalzonae and Alice serovars reflects the ability of $L$. santarosai to produce clinical symptoms ranging from mild to severe, including Weil's syndrome and liver failure. Although other bacterial diseases can also cause increased acute phase proteins, this particular symptom may help in clinical management of the disease, mainly by aiding in the differentiation of leptospirosis from malaria, dengue, or other viral infections in patients with acute febrile disease. The interaction be- tween animals and human and its effect on public health is an open field for research. It is important to establish the main reservoirs of the disease in order to evaluate the magnitude of leptospirosis in Colombia.

\section{REFERENCES}

Adler B, Moctezuma AP. Leptospira and leptospirosis. Vet Microbiol. 2010; 140(3-4): 287-96.

Benschop J, Heuer C, Jaros P, Collins-Emerson J, Midwinter A, Wilson P. Sero-prevalence of leptospirosis in workers at a New Zealand slaughterhouse. N Z Med J. 2009; 122(1307): 39-47.

Bharti A, Nally J, Ricaldi J, Matthias M, Diaz M, Lovett M, et al. Leptospirosis: a zoonotic disease of global importance. Lancet Infect Dis. 2003; 3(12): 757-71.

Boonsilp S, Thaipadungpanit J, Amornchai P, Wuthiekanun V, Bailey $\mathrm{M}$, Holden M, et al. A single multilocus sequence typing (MLST) scheme for seven pathogenic Leptospira species. PLoS Negl Trop Dis. 2013; 7(1): e1954.

Bourhy P, Storck CH, Theodose R, Olive C, Nicolas M, Hochedez P, et al. Serovar diversity of pathogenic Leptospira circulating in the French West Indies. PLoS Negl Trop Dis. 2013; 7(3): e2114.

Carmona-Gasca C, Lara L, Castillo-Sánchez L, Ramírez-Ortega J, Ko A, Palomera C, et al. Detection of Leptospira santarosai and L. kirschneri in cattle: new isolates with potential impact in bovine production and public health. Vet Méx. 2011; (42): 277-88.

CDC - Centers for Disease Control and Prevention. Outbreak of acute febrile illness among athletes participating in triathlons Wisconsin and Illinois, 1998. MMWR Morb Mortal Wkly Rep. 1998; 47(28): 585-8.

Cerqueira G, Picardeau M. A century of Leptospira strain typing. Infect Genet Evol. 2009; 9(5): 760-8.

Desai S, van Treeck U, Lierz M, Espelage W, Zota L, Sarbu A, et al. Resurgence of field fever in a temperate country: an epidemic of leptospirosis among seasonal strawberry harvesters in Germany in 2007. Clin Infect Dis. 2009; 48(6): 691-7.

Epstein P, Calix O, Blanco J. Climate and disease in Colombia. Lancet. $1995 ; 346(8985)$ : 1243-4.

Evangelista K, Coburn J. Leptospira as an emerging pathogen: a review of its biology, pathogenesis and host immune responses. Future Microbiol. 2010; 5(9): 1413-25.

Ferro B, Rodríguez A, Pérez M, Travi B, Ferro B, Rodríguez A, et al. Seroprevalence of Leptospira infection in habitants of peripheral neighborhoods in Cali, Colombia. Biomedica. 2006; (26): 250-7.

Galloway R, Levett P. Application and validation of PFGE for serovar identification of Leptospira clinical isolates. PLoS Negl Trop Dis. 2010; 4(9): e824.

Kmety E, Dikken H. Classification of the species Leptospira interrogans and history of its serovars. Groningen: University Press Groningen; 1993.

Larkin M, Blackshields G, Brown N, Chenna R, Mcgettigan P, McWilliam H, et al. Clustal W and Clustal X version 2.0. Bioinformatics. 2007; 23(21): 2947-8.

Levett P, Morey R, Galloway R, Steigerwalt A. Leptospira broomii sp. nov., isolated from humans with leptospirosis. Int J Syst Evol Microbiol. 2006; 56(3): 671-3.

Machry L, Ribeiro R, Vital-Brazil J, Balassiano I, de Oliveira I, Avelar K, et al. Characterization of Leptospira sp reference strains using the pulsed field gel electrophoresis technique. Rev Soc Bras Med Trop. 2010; 43(2): 166-9. 
Morgan J, Bornstein S, Karpati A, Bruce M, Bolin C, Austin C, et al. Outbreak of leptospirosis among triathlon participants and community residents in Springfield, Illinois, 1998. Clin Infect Dis. 2002; 34(12): 1593-9.

Nájera S, Alvis N, Babilonia D, Alvarez L, Máttar S. Occupational leptospirosis in a Colombian Caribbean area. Salud Publica Mex. 2005; 47(3): 240-4.

Ochoa J, Sánchez A, Ruiz I. Epidemiología de la leptospirosis en una zona andina de producción pecuaria. Rev Panam Salud Publica. 2000; 7(5): 325-31.

Petrakovsky J, Bianchi A, Fisun H, Najera-Aguilar P, Pereira M. Animal leptospirosis in Latin America and the caribbean countries: reported outbreaks and literature review (2002-2014). Int J Environ Res Public Health. 2014; 11(10): 10770-89.

Rivera P, Ticlla M, Balda L, González D, Céspedes M. Genetic diversity of Peruvian isolates of Leptospira spp. through pulsed field gel electrophoresis. Rev Peru Med Exp Salud Publica. 2012; 29(4): 469-76.

Romero M, Sánchez J, Hayek L. The prevalence of antibodies against Leptospira in urban human and canine populations from the Tolima department. Rev Salud Publica. 2010; 12(2): 268-75.

Romero-Vivas C, Cuello-Pérez M, Agudelo-Flórez P, Thiry D, Levett P, Falconar A. Cross-sectional study of Leptospira seroprevalence in humans, rats, mice, and dogs in a main tropical sea-port city. Am J Trop Med Hyg. 2013a; 88(1): 178-83.

Romero-Vivas C, Thiry D, Rodríguez V, Calderón A, Arrieta G, Máttar S, et al. Molecular serovar characterization of Leptospira isolates from animals and water in Colombia. Biomedica. 2013b; 33(1): 179-84.
Saito M, Villanueva S, Kawamura Y, Iida K, Tomida J, Kanemaru $\mathrm{T}$, et al. Leptospira idonii sp. nov., isolated from environmental water. Int J Syst Evol Microbiol. 2013; 63(7): 2457-62.

Sebek Z, Sixl W, Valova M, Marth E, Kock M, Reinthaler F. Serological investigations for leptospirosis in humans in Columbia. Geogr Med Suppl. 1989; 3: 51-60.

Stern E, Galloway R, Shadomy S, Wannemuehler K, Atrubin D, Blackmore $\mathrm{C}$, et al. Outbreak of leptospirosis among adventure race participants in Florida, 2005. Clin Infect Dis. 2010; 50(6): 843-9.

Szonyi B, Agudelo-Flórez P, Ramírez M, Moreno N, Ko AI. An outbreak of severe leptospirosis in capuchin (Cebus) monkeys. Vet J. 2011; 188(2): 237-9.

Tamura K, Peterson D, Peterson N, Stecher G, Nei M, Kumar S. MEGA5: molecular evolutionary genetics analysis using maximum likelihood, evolutioanry distance, and maximum parsimony methods. Mol Biol Evol. 2011; 28(10): 2731-9.

Tenover F, Arbeit R, Goering R, Mickelsen P, Murray B, Persing D, et al. Interpreting chromosomal DNA restriction patterns produced by pulsed- field gel electrophoresis: criteria for bacterial strain typing. J Clin Microbiol. 1995; 33(9): 2233-9.

Valverde A, Ramírez J, de Oca LM, Goris M, Ahmed N, Hartskeerl R. Arenal, a new Leptospira serovar of serogroup Javanica, isolated from a patient in Costa Rica. Infect Genet Evol. 2008; 8(5): 529-33.

Vasconcellos S, Oliveira J, Morais Z, Baruselli P, Amaral R, Pinheiro $\mathrm{S}$, et al. Isolation of Leptospira santarosai, serovar guaricura from buffaloes (Bubalus bubalis) in Vale do Ribeira, São Paulo, Brazil. Braz J Microbiol. 2001; 32(4): 298-300.

WHO - World Health Organization. Human leptospirosis: guidance for diagnosis, surveillance and control. WHO Library. 2003; (45): 1-109. 